\title{
Gusev A.V••
}

DOI: 10.25108/2304-1730-1749.iolr.2018.57.60-82

\section{Organizational tactical problems of using special criminalistical knowledge}

\begin{abstract}
Since the specialists-criminalists always assist to an investigator in solution on collection of material evidence and also the tasks on more accurate reflection of a process and the results of conducting investigative actions then interaction of investigators to the bodies, which carrying out expert criminalistical activity, is a mandatory at production of preliminary investigation.

Interaction of persons, who conduct preliminary investigation, with other participants of this process, including the specialists-criminalists, is in a sense conditional. Form procedural point of view there is no equal partnership here, a status of investigator determines his mastering and leading role, personal responsibility for decisions made and the results of investigation in whole. Activity of other participants of investigation is subordinated to the tasks that set before them by an investigator and is agreed with him.
\end{abstract}

Keywords: special criminalistical knowledge; special knowledge; specialistcriminalist; investigator; preliminary investigation; criminal procedural law; investigation of crimes.

As it commonly known detection of evidence is a process of their finding, i.e. exposure, selection from environment, drawing attention to those or other actual data, which have evidential significance, and also taking these factual data. Law provided the right to gather evidence only a certain subjects: to a person conducting an inquest, operation officer, who on instruction of investigator,

- Gusev Aleksei Vasilevich - Doctor of Law, Professor, Associate Professor of the Department for Criminalistcs, Colonel of Police. Krasnodar University of the MIA of Russian Federation, Krasnodar, Russia. E-mail: kriminalistika_krdu@mvd.ru 
conducts certain investigative act, an investigator, prosecutor and court. Nobody, except them, has the right to conduct procedural actions on gathering proofs $[2, \mathrm{p}$. $29,32]$.

Unfortunately, persons who carry out preliminary investigation, do not command often with sufficient special criminalistical knowledge in order to apply rightly the technical and criminalistical means and methods in course of gathering (search, detection, fixation, seizure) of the material traces of crime and other material proofs. In addition, separate fulfillment of this job becomes complicated due to labour intensity of this process. As result, "one of the common of shortcomings of detection, investigation and prevention of crimes is nonapplication or wrong application by investigators the technical and criminalistical means and methods, tactical techniques and recommendations" [28, p. 165].

Indicated circumstances have required a wide participation of employees of expert criminalistical services in course of preliminary investigation. In this connection S.T. Zernov writes: "Despite potentially wide circle of the subjects of application of special knowledge, at the stage of preliminary investigation this knowledge are applied mainly in form of participation of a specialist in investigative actions at searching of proofs and an expert - at production of expert examination" [8, p. 92].

Since specialists-criminalists always "assist to an investigator in solution on collection of material evidence and also the tasks on more accurate reflection of a process and the results of conducting investigative actions" [17, p. 45] then interaction of investigators to the bodies, which carrying out expert criminalistical activity, is a mandatory at production of preliminary investigation.

In opinion of some scientists, a success of investigation is achieved as long as between participants of searching and identifying activity exist an optimal interaction in the frames of specialized investigative group [11, p. 63]. Thus, one 
of the conditions of increasing effectiveness of crimes' investigation is a proper interaction an investigator with specialist-criminalist [1, p. 7].

"Problems of using special knowledge in preliminary investigation are researched by many but their attention compelled to procedural issues, not leaving place for investigative tactics" [25, p. 3-4]. Organizational tactical problems of using of specialist-criminalist's knowledge in course of preliminary investigation lead to loss of criminalistically significant information or its wrong usage.

Speaking on organizational tactical problems of using of special criminalistical knowledge during preliminary investigation, we should remember that interaction of the persons, who carry out preliminary investigation, with other participants of this process, including the specialists-criminalists, is in a sense conditional. Form procedural point of view there is no equal partnership here, a status of investigator determines his mastering and leading role, personal responsibility for decisions made and the results of investigation in whole. Activity of other participants of investigation is subordinated to the tasks that set before them by an investigator and is agreed with him [13, p. 491; 15, p. 113-114; 7, p. 29].

Thus, an investigator was and is the main chain of considered by us interaction, which is "free at making decisions on direction of investigation and production of investigative acts" [23, p. 11], "other participants of interaction subordinated to the task that sets before investigator; their actions have subsidiary nature" [4, p. 103].

Specialist has no procedural self-dependence [20, p. 23], his activity is limited with the frames of scientific technical aid used at conducting investigative act [18, p. 34], therefore in order to arrange his interaction with specialistcriminalist in right way investigator has to clearly image himself direction his activity and to know the means and methods of realization his special criminalistical knowledge in a specific situation. For instance, authorizing the 
specialist-criminalist to make photography, an investigator is obliged to indicate the objects of shooting, from what points and at what techniques they should be fixed [10, p. 171].

Unfortunately, not all investigators envision properly the directions of using the knowledge of specialists-criminalists as criminal procedural law does not contain a clear regulation of their tasks and functions. As result, at selfdependence determination of these tasks, investigators often make organizational tactical mistakes, which, as it well-known, are related to one of the kinds of investigatory and judicial mistakes [9, p. 286-288].

"Whether always investigators manage effectively with work of specialistscriminalists?" - at this question 92.9\% questioned by us employees of expert criminalistical service of the MIA of Russia gave negative response. "Many investigators who have a little experience of work and obviously insufficient professional level of training, not always may take himself organizing role in disclosure of crimes, therefore there is slowly going an introduction of the modern forms and methods of organization of investigatory groups in investigative practice, and first of all, in place of incident..." [19, p. 11-32].

As result, at bringing an accusation the evidential essence of the results of an investigators-criminalists' work is emasculated, and this is one of the reasons of a formal approach of an investigator to bringing an accusation [26, p. 94-97].

To the factors, which negatively influence in correct organization of interaction of an investigator with specialist-criminalist, first of all, should be related a weak lightness of this issue in criminal procedural legislation of Russia. So, based on norms of law, we may determine that a specialist-criminalist is obliged to use his special knowledge in assisting to investigator in detection, fixation and seizure of proof, but the form and order of such assistance is determined not by law and a specific investigator. 
By-laws concerning organization of a work of specialists in course of investigation of criminal case are also not concrete in relation to the form of participation of specialists-criminalists during investigatory acts. For example, it established that specialist-criminalist assists to investigator in detection, fixation, seizure, packaging and saving of the traces and other material proofs, at selection of comparative and test samples, and also other aid that requires a special knowledge

As it seems 'assistance' or 'granting the aid' are very unspecific notions. Their literal interpretation means that an investigator himself fulfills a main work on detection, fixation, seizure, packaging and saving of the traces and other material proofs, selection of comparative and testing samples, and a specialistcriminalist only helps him in that, moreover, time, place and range of this help is determined by the investigator. So for example, G.I Gramovich points out that investigator is obliged the both to inform a specialist what task he has taken part and to indicate where, when and what scientific technical means reasonable to apply. In addition, he is obliged to control the actions of a specialist [6, p. 22].

The absence of a clear indication in the law of the rights and obligations of specialists-criminalists, as well as the forms and methods of their activities, and attributing these issues to a competence of the persons, which conduct preliminary investigations, in our opinion, leads to an emergence of prerequisites for organizational and tactical errors of the interaction that we are considering and moreover, violates the right to defence [5, p. 87-95].

Certainly, presently all issues of organization of interaction of the services of the MIA of Russia in detection and investigation of crimes are reflected the both in departmental orders and developed methodic handbooks [24, p. 18] that dedicated to the tactics of conducting the investigatory acts. Unfortunately, many criminalistical recommendations leave the right of interaction's form with specialist for the person who carries out preliminary investigation. Though, 
"coherence in a work is achieved through rational combination of the measures that inherent to the subjects of interaction. However, the latter presupposes also clearly differentiation of rights and obligations between participants of united action. Everybody of them, being acted in the frames of his competence, with help of his means and methods seeks to achieve a common purpose - to quick and complete disclosure of crime and disclosure the guilty persons" [14, p. 204].

As we see, one of the main principles of a proper organization of interaction is an obligatoriness of ensuring of established competence of the subjects of interaction. However, without differentiation of rights and obligations it cannot be established the bounds of their competence. Since the direction of activity of specialist-criminalist is always determined only with will of investigator, but not by law and criminalistical recommendations then a role of the specialistcriminalist is frequently underestimated by investigators. Sometimes "investigator by his numerous and often instructions to specialist-criminalist suppresses his initiative in application his special knowledge" [21, p. 103].

Actually, without permission of investigator nobody, including a specialistcriminalist, has the right independently to produce acts that violate an environment, move along a place of an incident, to take the items in hands etc. [12, p. 34]. Thus, a role of specialist participating in investigative action actually has reduced by some scientists to a level of 'technical assistant' [6, p. 24]. In our view, such role of specialist is similar position of 'an auxiliary worker'; moreover, he cannot be a scientific consultant of an investigator [16, p. 46], though $83.7 \%$ of questioned investigators are considering a specialist-criminalist as technical assistant and scientific consultant of a person carrying out a preliminary investigation.

We should note that some scientists allow an independence of specialistcriminalist in the issues of search, detection, fixation and seizure of material traces of crime and other material proofs, however they do not indicate the 
bounds of such independence. In particular, N.A. Selivanov notes: "specialist participating in inspection of a place of incident may advise to investigator to extend an area of searching of material evidence and in known extent to take the initiative" $[25$, p. 8].

As we see, scientists 'in known extent' allow an independence of specialistcriminalist - his initiative, but since the bounds of such independence nowhere and no way is determined then they are established by investigator or specialistcriminalist, which at his own peril and risk, expanding a scope of the task assigned to him by investigator. Unfortunately, the practice knows the cases when specialists were authorized with duties not peculiar them, for example, guarding of a place of production of investigative act, fulfillment of auxiliary works. However incorrect organization of work on using special knowledge may cause to conflict between the subjects of interaction. In opinion of V.M. Bykov, no coincidence of interests of participants of interaction leads to an open or hidden struggle between them, mutual discontent, complaints, etc. [3, p. 69-70].

A survey of experts-criminalists who took part in investigative actions as specialists-criminalists showed that $68.9 \%$ of them had cases when their opinion on using of special criminalistical knowledge was different from the opinion of those conducting a preliminary investigation. In our opinion, these disagreements are the grounds for conflict between persons conducting a preliminary investigation and specialists-criminalistics.

Some scientists, assuming the occurrence of this conflict situation, advised the forensic specialist to quickly and quietly remove psychological barriers between him and the investigator, which may occur due to the fact that investigator does not have the same knowledge in a field of criminalistics and cannot understand the explanations of a specialist, and also due to the fact that when a joint action is performed, the investigator performs his part of work of fixing, for example, traces, less cleverly, not so quickly and accurately as specialists. 
Considering this point of view, it should be noted that its author entrusted the task of preventing a conflict situation to specialist-criminalist. Why should a specialist do this? If an investigator does not carefully remove the traces, then he should not take it at all, and in this situation specialist-criminalist should not become his teacher. If we imagine that the specialist-criminalist failed to prevent a conflict, then a psychological confrontation may arise between him and investigator, which would jeopardize conducting of the entire investigative action as a whole.

In our view, imperfectness of criminal procedural law and by-laws, and also criminalistical recommendations on interaction of the persons, which carry out preliminary investigation, with specialists-criminalists leads to emergence of organizational tactical errors of application and usage of special criminalistical knowledge in course of preliminary investigation.

\section{References}

1. Alekseev A.A., Kapitonov V.E. Predvaritel'noe kriminalisticheskoe issledovanie material'nykh sledov na meste proisshestviya [Preliminary criminalistical examination of material traces at place of incident]. Ucheb.posobie [Teaching aid]. Moscow, 1988, $542 \mathrm{p}$.

2. Belkin R.S. Sobiranie, issledovanie i otsenka dokazatel'stv. Suschost' i metody [Collection, examination and evaluation of proofs. Essence and methods]. Moscow, 1966, 295 p.

3. Bykov V.M. Prestupnaya gruppa: kriminalisticheskie problem [Criminal group: criminalistical problems]. Tashkent, 1991, 143 p.

4. Vologin S.M. Problemy organizatsii vzaimodeistviya sledovatelya s predstavitelyami organa doznaniya [Problems of organization of interaction of investigator with representatives of an inquiry body] // Problemy organizatorskoi 
raboty sledovatelya [Problems of organizational work of investigator]. Volgograd, 1991, pp. 58-67.

5. Gorb Yu.V. Zayavlennya klopotannya zakhisnikom pro provedennya ekspertizi na etapi dosudovogo provadzhennya [Submission of petition on conducting an expert-examination at the stage of pre-trial production]. Almanakh miznarodnogo prava [Almanac of international law]. Issue no. 18, 2018, pp. 87-95

6. Gramovich G.I. Taktika ispol'zovaniya spetsial'nykh znani v raskrytii I rassledovanii prestupleniyi [Tactics of use of special knowledge in detection and investigation of crimes]. Ucheb.posobie [Teaching aid]. Minsk, 1987, 276 p.

7. Gulyaev A.P. Sledovatel' v ugolovnom protsesse [Investigator in criminal process]. Moscow, 1981, 192 p.

8. Zernov S.I. Teoreticheskie i prikladnye problemy primeneniya spetsial'nykh poznanyi pri vyayvlenii i rassledovanii prestupleniyi, soprayzhennykh s pozharami [Theoretical and applied problems of application of special knowledge at disclosure and investigation of crimes connected with fire]. Dis... dokt. yurid. nauk [Dissertation of Doctor of Law]. Moscow, 1997, 517 p.

9. Zorin G.A. Teoreticheskie osnovy kriminlistiki [Theoretical basis of criminalistics]. Minsk, 2000, 608 p.

10. Ischenko E.P., Ischenko P.P., Zotchev V.A. Kriminalisticheskaya fotografiya i videozapis' [Criminalistical photography and video-recording]. Ucheb.-prakt.posobie [Teaching aid]. Pod red. E.P. Ischenko [Ed. by E.P. Ischenko]. Moscow, 1999, 438 p.

11. Kokurin G.A. Organizatsionnye osnovy deaytel'nosti sledstvennooperativnykh grup [Organizational basis of activity of investigative groups]. Moscow, 1997, $68 \mathrm{p}$.

12. Kolmakov V.P. Sledstvennyi osmotr [Investigative inspection]. Moscow, $1969,196 \mathrm{p}$. 
13. Kriminalistika. Uchebnik dlya vuzov [Criminalistics. Textbook for Universities]. Pod red. R.S. Belkina [Ed. by R.S. Belkin]. Moscow, 1999, 990 p.

14. Kriminalistika. Uchebnik [Criminalistics. Textbook]. Pod red. A.G. Filippova [Ed. by A.G. Filippov]. Moscow, 1998, 543 p.

15. Larin A.M. Rassledovanie po ugolovnomu delu: protsessual'nye funktsii [Investigation on criminal case: procedural functions]. Moscow, 1986, $160 \mathrm{p}$.

16. Lopushnoyi E.Ya. Uchastie spetsialista-kriminalista $\mathrm{v}$ sledstvennykh deyistviyakh [Participation of specialist-criminalist in investigative acts]. Dis... kand. yurid. nauk [Dissertation of PhD in Law]. Almaty, 1971, 169 p.

17. Makhov V.N. Uchastie spetsialistov $\mathrm{v}$ sledstvennykh deyistviyakh [Participation of specialists in investigative actions]. Moscow, 1975, 298 p.

18. Melnikova E.B. Uchastie spetsialistov $\mathrm{v}$ sledstvennykh deyistviyakh [Participation of specialists in investigative actions]. Moscow, 1964, 224 p.

19. O rezul'tatakh raboty organov predvaritel'nogo sledstviya v 1998 g.: Analiticheskaya spravka SK pri MVD Rossii [On results of work of bodies of preliminary investigation in 1998: Analytical reference of IC under the MIA of Russia]. Inf. bul. SK MVD Rosii [Infor. bul. of IC of the MIA of Russia]. 1999. No. 2, pp. 11-32.

20. Orlov Yu.K. Zaklyuchenie eksperta i ego otsenka po ugolovnym delam [Expert opinion and its assessment on criminal cases]. Ucheb.posobie [Teaching aid]. Moscow, 1995, 64 p.

21. Poroshin G.N. Nekotorye voprosy organizatsii vzaimodeyistviya sledovatelya so spetsialistom-kriminalistom pri proizvodstve sledstvennykh deyistviyi [Some issues of organization of interaction of investigator with specialist-criminalist at production of investigative actions]. Problemy organizatorskoyi raboty sledovatelya [Problems of organizational work of investigator]. Sb.nauchn.tr. VSSh MVD SSSR. Volgograd, 1991, 369 p. 
22. Protsessual'nye i kriminalisticheskie problem deyatel'nosti organov doznaniya [Procedural and criminalistical issues of activity of inquiry bodies]. Saratov, 2000, 41 p.

23. Rukovodstvo dlya sledovateleyi [Guidelines for investigators]. Pod red. N.A. Selivanova, V.A. Snetkova [Ed. by N.A. Selivanov, V.A. Snetkov]. Moscow, 1998, $732 \mathrm{p}$.

24. Sedova G.I. Protsessual'nye i kriminalisticheskie problem deyatel'nosti organov doznaniya [Procedural and criminalistical problems of activity of bodies of inquiry]. Avtoref.dis...kand.yurid.nauk [PhD in Law Author's Abstract]. Saratov, 2000, 68 p.

25. Selivanov N.A. Privlechenie spetsialista $\mathrm{k}$ rassledovaniyu [Bringing of specialist to investigation]. Moscow, 1973, 536 p.

26. Solodkaya V.I. K voprosu o deyatel'nosti sledovatelya na etape privlecheniya $\mathrm{v}$ kachestve obvinyaemogo [To an issue on activity of investigator at the stage of bringing as accused]. Obschestvo: politika, ekonomika, pravo [Society: policy, economics, law]. Issue no. 8, 2018, pp. 94-97.

27. Sorokotyagin I.N. Spetsial'nye poznaniya $v$ rassledovanii prestupleniyi [Special knowledge in investigation of crimes]. Rostov on Don, 1984, 119 p.

28. Tlish A.D. Ispol'zovanie dostizheniyi kibernetiki v raskrytii, rassledovanii obscheugolovnykh prestupleniyi, a takzhe v sfere ekonomicheskoyi deyatel'nosti, sovershaemykh s ispol'zovaniem kompyuternoyi i inoyi tekhnologii [Usage of achievements of cybernetics in detection, investigation common-criminal crimes, and also in sphere of economic activity, committed with usage of computer and other technology]. Ucheb.-prakt.posobie [Teaching aid]. Pod red. G.M. Meretukova [Ed. by G.M. Meretukov]. Krasnodar, 2000, 231 p. 